Jagoda Jaskulska (1) https://orcid.org/0000-0002-0904-0207

Uniwersytet Mikołaja Kopernika w Toruniu

Maciej Jaskulski (iD https://orcid.org/0000-0002-4247-5114

Collegium Medicum im. Ludwika Rydygiera w Bydgoszczy

Uniwersytet Mikołaja Kopernika w Toruniu

\title{
DYŻUR MEDYCZNY A KODEKSOWA REGULACJA DYŻURU PRACOWNICZEGO W ŚWIETLE STANDARDÓW POZAKRAJOWYCH
}

\begin{abstract}
Medical duty versus the code-based regulation of employee duty in the light of the non-national standards

Employee's duty is one of the institutions of general labour law, regulated in the Labour Code. However, with regard to medical professionals employed in healthcare institutions, the legislator introduced special provisions in this respect, prior to the general code regulation. Employee's duty has also been the subject of numerous considerations by the Court of Justice of the European Union. In Poland, only with regard to medical duty, the wording of national provisions has been adapted to EU law and the interpretation of the Court of Justice. The aim of this article is to analyse the legal nature of employee's duty and medical duty in terms of non-national standards, especially the interpretation made by the Court of Justice in this respect.
\end{abstract}

Słowa kluczowe: dyżur pracowniczy, dyżur medyczny, czas pracy

Keywords: employee's duty, medical duty, working time

ASJC: 3308, JEL: K31

\section{Wprowadzenie}

Dyżur jest jedną z instytucji powszechnego prawa pracy unormowaną w dziale szóstym ustawy z dnia 26 czerwca 1974 r. - Kodeks pracy (Dz.U. 2020, poz. 1320 tekst jedn. ze zm., dalej: „k.p.”). Jednak w odniesieniu do osób wykonujących zawód medyczny, zatrudnionych w podmiotach leczniczych, ustawodawca wprowadził w tym zakresie 
przepisy szczególne, wyprzedzające względem ogólnej regulacji kodeksowej. Dyżur stał się również przedmiotem licznych rozważań Trybunału Sprawiedliwości Unii Europejskiej (dalej: „TSUE”), który wypracował na tym gruncie jednolite i wiążące dla państw członkowskich stanowisko. W Polsce tylko w odniesieniu do dyżuru medycznego brzmienie przepisów krajowych zostało dostosowane do prawa unijnego i wykładni TSUE. Celem artykułu jest analiza charakteru prawnego dyżuru pracowniczego i dyżuru medycznego pod kątem standardów pozakrajowych, zwłaszcza wykładni dokonywanej w tym zakresie przez TSUE.

\section{Kodeksowa regulacja dyżuru pracowniczego}

W stosunku pracy pracodawca jest stroną odpowiedzialną za organizację procesu pracy. Dysponuje w tym zakresie pewnymi uprawnieniami. Jednym z nich jest możliwość zobowiązania pracownika do pozostawania w gotowości do wykonywania pracy także poza normalnymi godzinami pracy, co odpowiada kodeksowej definicji dyżuru. Instytucja ta została uregulowana $\mathrm{w}$ art. $1515 \mathrm{k} . p$. Zgodnie $\mathrm{z}$ jego brzmieniem pracodawca może polecić pracownikowi pełnienie dyżuru w zakładzie pracy albo w innym wyznaczonym miejscu, w tym na przykład w domu pracownika (zob. wyrok Sądu Najwyższego z dnia 13 maja 2009 roku, III PK 8/09, LEX nr 509014). Dyżurem w innym wyznaczonym miejscu będzie również tak zwany dyżur pod telefonem (wyrok Sądu Najwyższego z dnia 9 grudnia 2011 roku, II PK 115/11, OSNP 2013, nr 9-10, poz. 103). Polecenie pozostawania w gotowości do wykonywania pracy w ramach dyżuru może dotyczyć tylko pracy wynikającej z umowy o pracę (Pisarczyk 2017; Stefański 2020).

Ustawodawca przyjął, że czas dyżuru nie wlicza się do czasu pracy, jeśli podczas dyżuru pracownik nie świadczył pracy. Niezależnie od tego, czas dyżuru nie może naruszać prawa pracow ników do okresów odpoczynku uregulowanych w art. 132 i 133 k.p., to jest prawa do co najmniej 11 godzin nieprzerwanego odpoczynku w ciągu doby oraz do co najmniej 35 godzin nieprzerwanego odpoczynku w tygodniu. Zgodnie $z$ art. $1515 \$ 3$ k.p. za czas dyżuru pełnionego w innym miejscu niż miejsce zamieszkania pracownikowi przysługuje czas wolny od pracy w wymiarze odpowiadającym długości dyżuru, a w razie braku możliwości udzielenia czasu wolnego - wynagrodzenie wynikające z jego osobistego zaszeregowania, określonego stawką godzinową lub miesięczną, a jeżeli taki składnik wynagrodzenia nie został wyodrębniony przy określaniu warunków wynagradzania $60 \%$ wynagrodzenia. $Z$ zakresu podmiotowego przywołanych gwarancji wyłączeni zostali pracownicy zarządzający w imieniu pracodawcy zakładem pracy w rozumieniu art. $128 \$ 2$ pkt 2 k.p.

W doktrynie prawa pracy wskazuje się jednak, że literalna wykładnia art. 1515 $\$ 3$ k.p. - w zakresie, w jakim okres dyżuru rekompensowany jest dniem wolnym od pracy przy jednoczesnym braku wyraźnego wskazania, że pracownik zachowuje w tym czasie prawo do wynagrodzenia - może prowadzić do absurdalnych wniosków, stąd zaleca się w tym przypadku dokonywanie wykładni systemowej i funkcjonalnej 
(Szmit 2014, s. 30-31). Pracownicy pełniący dyżur w domu, o ile nie zostaną w tym czasie wezwani do wykonywania pracy, nie otrzymują w zamian żadnej rekompensaty. Nie stoi to jednak na przeszkodzie ku temu, by taką rekompensatę przewidywało prawo zakładowe. Za czas efektywnej pracy podczas dyżuru (niezależnie od tego, czy pracownik pełnił dyżur w zakładzie pracy, czy też stawił się w pracy, pełniąc dyżur $\mathrm{w}$ domu) pracownik otrzymuje wynagrodzenie jak za pracę w godzinach nadliczbowych (na zasadach określonych w art. 1511 k.p.).

\section{Dyżur medyczny}

W odniesieniu do niektórych grup zawodowych regulacja dotycząca dyżuru odbiega od wzorca ujętego w art. 1515 k.p. Przykładem takiego szczególnego unormowania jest art. 95 ustawy z dnia 15 kwietnia 2011 roku o działalności leczniczej (Dz.U. 2021 poz. 711 tekst jedn., dalej: „ustawa o działalności leczniczej”, „u.dz.l.”) utrzymujący w obrocie prawnym pojęcie dyżuru medycznego. Przepis ten odnosi się do pracowników wykonujących zawód medyczny i posiadających wyższe wykształcenie, zatrudnionych w podmiocie leczniczym wykonującym działalność leczniczą w rodzaju stacjonarne i całodobowe świadczenia zdrowotne. Zobowiązani do pełnienia dyżuru medycznego mogą być także pracownicy wykonujący zawód medyczny w jednostkach systemu Państwowego Ratownictwa Medycznego (z wyłączeniem lotniczych zespołów ratownictwa medycznego). W okresie stanu zagrożenia epidemicznego lub stanu epidemii dyżur medyczny mogą pełnić także osoby wykonujące zawód medyczny (to jest osoby uprawnione na podstawie odrębnych przepisów do udzielania świadczeń zdrowotnych oraz osoby legitymujące się nabyciem fachowych kwalifikacji do udzielania świadczeń zdrowotnych w określonym zakresie lub w określonej dziedzinie medycyny) zatrudnione w ramach stosunku pracy w podmiocie leczniczym (art. 47a ustawy z dnia 5 grudnia 2008 roku o zapobieganiu oraz zwalczaniu zakażeń i chorób zakaźnych u ludzi, Dz.U. 2020, poz. 1845 tekst jedn. ze zm.). Dyżurem medycznym jest wykonywanie czynności zawodowych poza normalnymi godzinami pracy w wymienionych podmiotach, co na gruncie przepisów ustawy o działalności leczniczej zasadniczo oznacza pracę w dniu będącym dla pracownika dniem pracy, ale po upływie 7 godzin i 35 minut pracy (w podstawowym systemie czasu pracy), albo w dniu wolnym od pracy zgodnie z obowiązującym pracownika rozkładem czasu pracy. Ustawodawca dopuścił możliwość planowania pracy w ramach dyżuru medycznego także w zakresie, w jakim ta będzie przekraczać tygodniową normę czasu pracy w podmiotach leczniczych, to jest 37 godzin 55 minut w przyjętym okresie rozliczeniowym, nie więcej jednak niż 48 godzin na tydzień (chyba że pracownik wyraził na to pisemną zgodę w ramach tak zwanej klauzuli opt-out, art. 96 ust. 1 u.dz.l.). Maksymalny okres trwania dyżuru medycznego musi zamykać się w obrębie 24 godzin od momentu rozpoczęcia pracy (maksymalna długość dyżuru w dniu wolnym od pracy wynosi zatem 24 godziny, a w dniu pracy - 16 godzin i 25 minut), z zastrzeżeniem, że naruszony w ten sposób 
11-godzinny okres odpoczynku dobowego powinien zostać udzielony pracownikowi bezpośrednio po zakończeniu dyżuru (art. 97 ust. 2 u.dz.l.; stanowisko Departamentu Prawnego Państwowej Inspekcji Pracy w sprawie charakteru prawnego dyżuru medycznego po 1 stycznia 2008 roku). Ponadto w przypadkach uzasadnionych organizacją pracy tygodniowy okres odpoczynku pracowników pełniących dyżur medyczny może ulec skróceniu - do 24 godzin nieprzerwanego odpoczynku, udzielanego w okresie rozliczeniowym nie dłuższym niż 14 dni.

W przeciwieństwie do kodeksowej regulacji dyżuru pracowniczego, czas pełnienia dyżuru medycznego - począwszy od 1 stycznia 2008 roku - w pełni wlicza się do czasu pracy, a pracownik otrzymuje w zamian wynagrodzenie jak za pracę w godzinach nadliczbowych - obliczone na podstawie art. $151 \$ 1-3$ k.p. (z wyjątkiem lekarzy stażystów, których zasady wynagradzania określają odrębne przepisy). Wyjaśnić należy, że powyższy sposób unormowania utrudnia określenie relacji zachodzącej pomiędzy dyżurem medycznym a pojęciem pracy w godzinach nadliczbowych w rozumieniu art. $151 \$ 1$ k.p. oraz dyrektywy 2003/88/WE Parlamentu Europejskiego i Rady z dnia 4 listopada 2003 roku dotyczącej niektórych aspektów organizacji czasu pracy (Dz.Urz. UE L 2003, nr 299/9, dalej: „dyrektywa 2003/88/WE”; zob. Kubot 2008, s. 17-18; Walasek-Walczak 2013; Bąba 2015, s. 10-14; Rek 2019; wyrok Sądu Najwyższego z dnia 16 grudnia 2014 roku, I PK 313/13, LEX nr 1628905). Należy również mieć na uwadze, że ustawodawca stworzył możliwość planowania dyżuru medycznego zarówno w ramach przeciętnej tygodniowej normy czasu pracy, jak i w zakresie przekraczającym tę normę. To oznacza, że dyżurem medycznym jest czas wykonywania czynności zawodowych poza normalnymi godzinami pracy przypadającymi pracownikowi do przepracowania $\mathrm{w}$ danej dobie, a nie poza obowiązującą pracownika przeciętną tygodniową normą czasu pracy. Powyższa interpretacja posłużyła Sądowi Najwyższemu do opowiedzenia się za dopuszczalnością dopełnienia dyżurem medycznym czasu pracy lekarza do obowiązującej go przeciętnej tygodniowej normy czasu pracy (uchwała składu siedmiu sędziów Sądu Najwyższego z dnia 6 listopada 2014 roku, I PZP 2/14, OSNP 2015, nr 4, poz. 46).

\section{Dyżur medyczny i dyżur pracowniczy w świetle dyrektywy 2003/88/WE i orzecznictwa Trybunału Sprawiedliwości Unii Europejskiej}

Klasyfikacja dyżuru medycznego jako czasu pracy jest wynikiem implementacji do polskiego porządku prawnego postanowień dyrektywy 2003/88/WE (zastępującej wcześniej obowiązującą w tym zakresie dyrektywę Rady 93/104/WE z dnia 23 listopada 1993 roku dotyczącą niektórych aspektów organizacji czasu pracy, Dz.Urz. UE L 1993, nr 307/18, dalej: „dyrektywa 93/104/WE”). Nowelizacja przepisów dotyczących dyżuru medycznego w tym zakresie miała miejsce jeszcze na gruncie już nieobowiązującej ustawy z dnia 30 sierpnia 1991 roku o zakładach opieki zdrowotnej (Dz.U. 1991, nr 91 poz. 408, 
przedmiotowa zmiana weszła w życie z dniem 1 stycznia 2008 roku) ${ }^{1}$. Wypracowane $\mathrm{w}$ tamtym czasie rozwiązanie przeniesiono następnie do ustawy o działalności leczniczej. Na nowy kształt regulacji prawnej wpływ miała przede wszystkim wykładnia postanowień dyrektyw 93/104/WE i 2003/88/WE dokonana przez TSUE.

Jednym z pierwszych orzeczeń, w którym TSUE zakwalifikował okres dyżuru pełnionego przez lekarzy w miejscu pracy w pełni za czas pracy był wyrok z dnia 3 października 2000 roku (wyrok TSUE z dnia 3 października 2000 roku w sprawie Sindicato de Médicos de Asistencia Pública (Simap) przeciwko Conselleria de Sanidad y Consumo de la Generalidad Valencian, C-303/98, ECLI:EU:C:2000:528). Natomiast w sytuacji, w której lekarze byli zobowiązywani, aby można się było z nimi w razie potrzeby skontaktować, TSUE za czas pracy uznał już tylko czas związany z rzeczywistym świadczeniem przez nich usług. Podobne stanowisko TSUE zajął w wyroku z dnia 9 września 2003 roku w sprawie Landeshauptstadt Kiel przeciwko Norbertowi Jaegerowi (C-151/02, ECLI:EU:C:2003:437), dodatkowo wyjaśniając, jak na gruncie dyrektywy 93/104/WE rozumieć pojęcia „czasu pracy” i „okresów odpoczynku” w przypadku dyżurów pełnionych przez lekarzy w szpitalu. Zgodnie z interpretacją zaprezentowaną w tym wyroku dyżur lekarza, w ramach którego jest on zobowiązany do fizycznej obecności w szpitalu, należy uznać w całości za czas pracy, nawet jeżeli pracownik ma prawo do odpoczynku w miejscu pracy, kiedy jego usługi nie są potrzebne. Konieczność przebywania w tym czasie w szpitalu w stanie gotowości do natychmiastowego udzielania świadczeń uniemożliwia lekarzowi swobodny wybór miejsca, w którym pozostaje w tak zwanym okresie oczekiwania, co zdaniem TSUE jest decydującym czynnikiem przemawiającym za uznaniem tego dyżuru w pełni za czas pracy (nawet jeśli pracodawca udostępnia w tym czasie lekarzowi specjalne pomieszczenie przeznaczone do odpoczynku). W kolejnych wyrokach TSUE podkreślał, że kwalifikacja okresu obecności pracownika w miejscu pracy jako czasu pracy w rozumieniu dyrektywy 93/104/WE nie może być uzależniana od natężenia pracy pracownika, bo jest ono jedynie pochodną obowiązku pozostawania w dyspozycji pracodawcy i nie znajduje się wśród elementów charakteryzujących czas pracy w rozumieniu tej dyrektywy (wyrok TSUE z dnia 1 grudnia 2005 roku w sprawie Abdelkader Dellas i inni przeciwko Premier ministre i Ministre des Affaires sociales, du Travail et de la Solidarité, C-14/04, ECLI:EU:C:2005:728).

W sprawie Jaegera TSUE podkreślił ponadto, że przyjęta w dyrektywie definicja czasu pracy, choć odnosi się do krajowych porządków prawnych, to powinna być rozumiana jednolicie we wszystkich państwach członkowskich. Dlatego nie powinno dochodzić do sytuacji, w których prawa pracowników do należytego uwzględniania okresu pracy i odpowiednich okresów odpoczynku są determinowane dodatkowymi warunkami na poziomie krajowym. Zgodnie z art. 2 dyrektywy 2003/88/WE czasem pracy jest każdy okres, podczas którego pracownik pracuje, jest do dyspozycji pracodawcy oraz

1 Art. 32j ustawy o zakładach opieki zdrowotnej zmieniony przez art. 1 pkt 6 ustawy z dnia 24 sierpnia 2007 roku o zmianie ustawy o zakładach opieki zdrowotnej oraz ustawy - Prawo o szkolnictwie wyższym (Dz.U. 2007, nr 176, poz. 1240). 
wykonuje swoje działania lub spełnia obowiązki, zgodnie z przepisami krajowymi lub praktyką krajową. Okresem odpoczynku jest natomiast każdy okres niebędący czasem pracy. Dyrektywa nie przewiduje istnienia w tym zakresie form pośrednich, zwłaszcza nie wprowadza ani nie definiuje pojęcia tak zwanych nieaktywnych okresów dyżurowania. Te ostatnie - choć mogą mieć znaczenie przy różnicowaniu sposobu wynagradzania pracowników pełniących dyżur w miejscu pracy - nie powinny wpływać na skuteczność praw wynikających z dyrektywy. Dyrektywa 2003/88/WE nie reguluje kwestii wynagradzania pracowników, bowiem Unia Europejska nie ma kompetencji do stanowienia prawa w tym zakresie. Nie będzie zatem naruszać postanowień dyrektywy krajowa regulacja prawna różnicująca sposób wynagradzania pracownika za okresy rzeczywistego świadczenia pracy w ramach dyżuru i okresy, w których praca nie była wykonywana (postanowienie TSUE z dnia 11 stycznia 2007 roku w sprawie Jan Vorel przeciwko Nemocnice Český Krumlov, C-437/05, ECLI:EU:C:2007:23).

W Polsce wykładnia TSUE doprowadziła co prawda do zmian w ustawodawstwie pracy, jednak tylko w odniesieniu do pracowników pełniących dyżur medyczny w rozumieniu przepisów ustawy o działalności leczniczej (a wcześniej ustawy o zakładach opieki zdrowotnej). Należy przy tym podkreślić, ze przepis art. 95 u.dz.l. o dyżurach medycznych odnosi się wyłącznie do pracowników, a więc osób zatrudnionych w tych podmiotach $\mathrm{w}$ ramach stosunku pracy. Poza zakresem tej regulacji pozostają przedstawiciele zawodów medycznych pełniący dyżury na innej podstawie niż stosunek pracy, w ramach umowy cywilnoprawnej czy na podstawie kontraktów cywilnoprawnych wykonywanych przez osoby prowadzące indywidualne praktyki w samodzielnych zawodach medycznych w takim przypadku wspomniane regulacje nie znajdują zastosowania (wyrok Sądu Najwyższego z dnia 17 stycznia 2019 roku, III PK 128/17, LEX nr 2607242). Szczegóły dotyczące sposobu pełnienia i wynagradzania dyżuru określają wówczas postanowienia kontraktu lub innej umowy cywilnoprawnej.

Kodeksowa regulacja dyżuru pracowniczego $\mathrm{w}$ dalszym ciągu pozostaje $\mathrm{w}$ sprzeczności z postanowieniami dyrektywy 2003/88/WE w zakresie, w jakim nie zalicza do czasu pracy tak zwanych nieaktywnych okresów dyżuru pełnionego w miejscu pracy. Problem ten był już wielokrotnie sygnalizowany w doktrynie prawa pracy (Piątkowski 2009, s. 205; Ostaszewski, Raczkowski 2012, s. 25-26). Sposób unormowania przyjęty w art. 1515 k.p. wciąż utrzymuje w obrocie prawnym pośrednią kategorię czasu dyżuru, podczas którego praca nie była wykonywana - niemożliwą do jednoznacznego zakwalifikowania ani jako czas pracy, ani jako okres odpoczynku (Majkowska-Szulc, Tomaszewska 2007, s. 56-57).

\section{Dyżur poza miejscem pracy na gruncie orzecznictwa Trybunału Sprawiedliwości Unii Europejskiej}

Czasem pracy nie jest natomiast czas pozostawania w gotowości do udzielania świadczeń zdrowotnych poza podmiotem leczniczym, na przykład w domu pracownika. Pracownik zobowiązany na podstawie art. 98 u.dz.l. do pozostawania w takiej gotowości otrzymuje 
w zamian za każdą godzinę wynagrodzenie w wysokości 50\% stawki godzinowej wynagrodzenia zasadniczego. Dopiero w przypadku wezwania go do podmiotu leczniczego stosuje się w tym zakresie przepisy obowiązujące na gruncie dyżuru medycznego. Z kolei kodeksowa regulacja dyżuru domowego, jak już wskazywano, nie przewiduje żadnej rekompensaty dla pracownika w zamian za pozostawanie w gotowości do wykonywania pracy w miejscu jego zamieszkania. Tymczasem najnowsze orzecznictwo TSUE wydaje się podążać w tym zakresie w nowym kierunku. W wyroku z dnia 21 lutego 2018 roku w sprawie Ville de Nivelles przeciwko Rudy'emu Matzakowi (C-518/15, ECLI:EU:C:2018:82) TSUE stwierdził, że również dyżur pełniony przez pracownika w miejscu zamieszkania w połączeniu z obowiązkiem stawienia się w krótkim czasie w miejscu pracy na wezwanie pracodawcy należy traktować jako czas pracy. Sprawa dotyczyła belgijskiego strażaka ochotnika ${ }^{2}$, który domagał się odszkodowania za okres pełnienia dyżuru domowego, podczas którego obowiązany był do stawienia się na wezwanie pracodawcy w ciągu ośmiu minut. Zdaniem TSUE, obowiązek ten znacząco ograniczał możliwość skupienia się przez pracownika na innych sprawach, przez co czas dyżuru również powinien być traktowany jako czas pracy. TSUE odmiennie potraktował jednak sytuację, w której pracownik pełni dyżur w systemie tak zwanego dyżuru pod telefonem bez obowiązku przebywania w miejscu pracy. Taki pracownik może rozporządzać swoim czasem w sposób mniej ograniczony, przez co w jego przypadku czasem pracy będzie wyłącznie czas, w którym efektywnie świadczył pracę.

Uwage w tym zakresie zwraca niedawny wyrok TSUE z dnia 9 marca 2021 roku w sprawie D.J. przeciwko Radiotelevizija Slovenija (C-344/19, ECLI:EU:C:2021:182), którego zaletą jest określenie wytycznych interpretacyjnych, jakie powinny towarzyszyć sądom krajowym przy ocenie charakteru prawnego dyżuru pełnionego poza miejscem pracy w kontekście dyrektywy 2003/88/WE. TSUE stwierdził, że okres pełnienia dyżuru poza miejscem pracy, podczas którego pracownik może zaplanować zajęcia natury osobistej i towarzyskiej oraz gdy przyznany mu został rozsądny czas na podjęcie czynności zawodowych, nie stanowi a priori czasu pracy (co oczywiście nie stoi na przeszkodzie ku temu, by regulacje krajowe, układy zbiorowe pracy czy decyzje pracodawcy przewidywały wynagrodzenie rekompensujące pracownikowi ewentualne niedogodności związane z pełnieniem dyżuru niekwalifikowanego jako czas pracy). Jednak już zredukowanie czasu na dotarcie do pracy do kilku minut przemawia za uznaniem takiego dyżuru w całości za czas pracy. Zdaniem TSUE, krótki czas na reakcję może bowiem skutkować silnym zniechęceniem pracownika do planowania jakiejkolwiek, nawet krótkotrwałej aktywności w czasie wolnym. Przy ocenie charakteru prawnego dyżuru sądy krajowe powinny badać także częstotliwość rzeczywistego świadczenia pracy przez pracownika w ramach dyżuru, ponieważ pracownik wielokrotnie wzywany w jego trakcie do pracy ma mniejszą swobodę w zakresie zarządzania czasem w okresach

2 Pomimo statusu strażaka ochotnika TSUE uznał go za pracownika w rozumieniu dyrektywy 2003/88/WE. Szerzej o autonomicznych pojęciach w prawie pracy w Unii Europejskiej: Świątkowski 2018, s. 10-13. 
niewykonywania pracy. Stąd częste i niekrótkotrwałe wezwania pracownika do pracy $\mathrm{w}$ trakcie dyżuru mogą przemawiać za tym, by okres ten w pełni traktować jako czas pracy. Przedstawione wytyczne posłużyły TSUE za podstawę rozstrzygnięcia także w sprawie RJ przeciwko Stadt Offenbach am Main (wyrok z dnia 9 marca 2021 roku, C-580/19, ECLI:EU:C:2021:183).

\section{Podsumowanie}

TSUE jednoznacznie zakwalifikował czas dyżuru pełnionego w miejscu pracy (tak zwanego zakładowego) w pełni jako czas pracy także wtedy, gdy pracownik nie wykonuje pracy, ale w pozostaje w gotowości do jej świadczenia. Co więcej, prezentowana przez TSUE linia orzecznicza wciąż ewoluuje. Analiza ostatnich wyroków ukazuje, że z perspektywy postanowień dyrektywy 2003/88/WE również dyżur pełniony poza miejscem pracy może zostać uznany za czas pracy, a ocena jego charakteru zależeć będzie przede wszystkim od intensywności ograniczeń nakładanych w tym czasie na pracownika, możliwości ich wpływu na zdolność do swobodnego zarządzania przez niego czasem w okresach, w których nie świadczy pracy, jak również częstotliwości i długości trwania interwencji podejmowanych w tym czasie przez pracownika. Coraz większą wagę przykłada się przy tym do zagrożeń psychospołecznych związanych z pełnieniem dyżuru, zwłaszcza gdy ten trwa bez przerwy, przez długie okresy bądź występuje w bardzo krótkich odstępach czasu lub w nocy. TSUE podnosi, że w takiej sytuacji pracownik może mieć problem $\mathrm{z}$ realnym „odseparowaniem się od środowiska pracy” w stopniu wystarczającym do zneutralizowania wpływu pracy na własne bezpieczeństwo i zdrowie.

Dotychczas wykładnia dokonana przez TSUE poskutkowała zmianą przepisów dotyczących dyżurów medycznych. Jednak kodeksowa regulacja dyżuru pracowniczego wciąż pozostaje niezgodna z przyjętymi na tym gruncie standardami unijnymi. Dodać należy, że w projekcie Kodeksu pracy z 2018 roku podjęto co prawda próbę dostosowania regulacji krajowej do prawa unijnego, lecz zaproponowane rozwiązania ostatecznie nie weszły w życie. Polska regulacja dyżuru pracowniczego nie jest wyjątkiem na tle ustawodawstw innych państw członkowskich, co jednak w dalszym ciągu nie usprawiedliwia istniejącego rozdźwięku pomiędzy prawem krajowym a dyrektywą 2003/88/WE. Zgłaszane w tym zakresie przez państwa członkowskie zastrzeżenia doprowadziły co prawda do złożenia w 2004 roku przez Komisję Europejską wniosku o zmianę dyrektywy 2003/88/WE (zob. Wniosek dotyczący dyrektywy Parlamentu Europejskiego i Rady zmieniającej dyrektywę 2003/88/WE dotyczącą niektórych aspektów organizacji czasu pracy, COM/2004/0607 końcowy - COD 2004/0209). Trudności w wypracowaniu porozumienia sprawiły jednak, że Parlament Europejski ostatecznie odrzucił proponowane zmiany, aprobując tym samym ukształtowaną $\mathrm{w}$ tym zakresie linię orzeczniczą. Nastał zatem czas na realizację postanowień dyrektywy w rozumieniu przyjętym przez TSUE, i to nie tylko w odniesieniu do personelu medycznego, ale także wobec wszystkich pracowników. Tymczasem - pomimo upływu lat - niewiele się w tym 
kierunku dzieje, co może dziwić, zważywszy zwłaszcza na podstawowe założenia, cele i przyjęte mechanizmy funkcjonowania w ramach Unii Europejskiej.

Być może jednym z powodów, dla których ustawodawca zwleka z dostosowaniem regulacji krajowej do standardów unijnych, jest obawa przed koniecznością jednoczesnego przewartościowania także innych instytucji prawa pracy, w tym przede wszystkim pojęcia pracy w godzinach nadliczbowych. Zakwalifikowanie całego okresu dyżuru zakładowego do czasu pracy wiązałoby się bowiem z wynagradzaniem jak za pracę w godzinach nadliczbowych nie tylko okresu wykonywania pracy, ale także okresu pozostawania w gotowości do jej wykonywania podczas dyżuru zakładowego, jak również uwzględniania takich nieaktywnych okresów dyżuru przy obliczaniu wymiaru czasu pracy pracownika.

W przyszłości istotny będzie także kierunek, w jakim podążą polskie sądy, orzekając w sprawach $\mathrm{z}$ analizowanego obszaru. Ponadto z wyroków TSUE - wydanych zwłaszcza w ostatnich sprawach - płynie wiele cennych wskazówek dla pracodawców co do tego, w jaki sposób organizować czas pracy. Chodzi tu zwłaszcza o nienakładanie na pracowników pełniących dyżur poza miejscem pracy uciążliwych ograniczeń, które uniemożliwiałyby swobodne zarządzanie przez pracownika czasem, w którym nie wykonuje pracy.

\section{Bibliografia}

Bąba M. (2015) Dyżur medyczny a praca w godzinach nadliczbowych, „Praca i Zabezpieczenie Społeczne", nr 4.

Kubot Z. (2008) Specyfika dyżurów medycznych, „Praca i Zabezpieczenie Społeczne”, nr 1.

Majkowska-Szulc S., Tomaszewska M. (2007) Czas pracy lekarzy - glosa do wyroku Sądu Okręgowego w Krakowie z 29.12.2006 r. (VI Pa 445/06), „Europejski Przegląd Sądowy”, nr 12.

Ostaszewski W., Raczkowski M. (2012) Konstrukcja instytucji dyżuru pracowniczego i jej praktyczne wykorzystanie, „Praca i Zabezpieczenie Społeczne”, nr 4.

Piątkowski J., Piątkowski P. (2009) Wybrane zagadnienia prawa pracy i prawa urzędniczego, Toruń.

Pisarczyk Ł. (2017) [w:] L. Florek (red.), Kodeks pracy. Komentarz, Warszawa, komentarz do art. 1515.

Rek T. (2019) [w:] M. Dercz, T. Rek (red.), Ustawa o działalności leczniczej. Komentarz, Warszawa, komentarz do art. 95.

Stefański K. (2020) [w:] K.W. Baran (red.), Kodeks pracy. Komentarz, Warszawa, komentarz do art. 1515.

Szmit J. (2014) Prawo do wynagrodzenia gwarancyjnego w świetle wybranych przepisów dotyczących czasu pracy, „Praca i Zabezpieczenie Społeczne”, nr 6.

Świątkowski A.M. (2018) Dyżur pracowniczy. Zagadnienia prawne dotyczące relacji pojęć „czas pracy” $i$ „okres wypoczynku” w świetle orzecznictwa Trybunału Sprawiedliwości Unii Europejskiej, „Przegląd Sądowy”, nr 11-12.

Walasek-Walczak U. (2013) [w:] F. Grzegorczyk (red.), Ustawa o działalności leczniczej. Komentarz, Warszawa, komentarz do art. 95. 


\section{Orzecznictwo}

Postanowienie TSUE z dnia 11 stycznia 2007 roku w sprawie Jan Vorel przeciwko Nemocnice Český Krumlov, C-437/05, ECLI:EU:C:2007:23.

Uchwała składu siedmiu sędziów Sądu Najwyższego z dnia 6 listopada 2014 roku, I PZP 2/14, OSNP 2015, nr 4, poz. 46.

Wyrok Sądu Najwyższego z dnia 13 maja 2009 roku, III PK 8/09, LEX nr 509014.

Wyrok Sądu Najwyższego z dnia 9 grudnia 2011 roku, II PK 115/11, OSNP 2013, nr 9-10, poz. 103.

Wyrok Sądu Najwyższego z dnia 16 grudnia 2014 roku, I PK 313/13, LEX nr 1628905.

Wyrok Sądu Najwyższego z dnia 17 stycznia 2019 roku, III PK 128/17, LEX nr 2607242.

Wyrok TSUE z dnia 3 października 2000 roku w sprawie Sindicato de Médicos de Asistencia Pública (Simap) przeciwko Conselleria de Sanidad y Consumo de la Generalidad Valencian, C-303/98, ECLI:EU:C:2000:528.

Wyrok TSUE z dnia 9 września 2003 roku w sprawie Landeshauptstadt Kiel przeciwko Norbertowi Jaegerowi, C-151/02, ECLI:EU:C:2003:437.

Wyrok TSUE z dnia 1 grudnia 2005 roku w sprawie Abdelkader Dellas i inni przeciwko Premier ministre i Ministre des Affaires sociales, du Travail et de la Solidarité, C-14/04, ECLI:EU:C:2005:728.

Wyrok TSUE z dnia 21 lutego 2018 roku w sprawie Ville de Nivelles przeciwko Rudy'emu Matzakowi, C-518/15, ECLI:EU:C:2018:82.

Wyrok TSUE z dnia 9 marca 2021 roku w sprawie D.J. przeciwko Radiotelevizija Slovenija, C-344/19, ECLI:EU:C:2021:182.

Wyrok TSUE z dnia 9 marca 2021 roku w sprawie RJ przeciwko Stadt Offenbach am Main, C-580/19, ECLI:EU:C:2021:183.

\section{Akty prawa międzynarodowego}

Dyrektywa Rady 93/104/WE z dnia 23 listopada 1993 roku dotycząca niektórych aspektów organizacji czasu pracy, Dz.Urz. UE L 1993, nr 307/18.

Dyrektywa 2003/88/WE Parlamentu Europejskiego i Rady z dnia 4 listopada 2003 roku dotycząca niektórych aspektów organizacji czasu pracy, Dz.Urz. UE L 2003, nr 299/9.

\section{Akty prawa krajowego}

Ustawa z dnia 26 czerwca 1974 roku - Kodeks pracy, Dz.U. 2020, poz. 1320 tekst jedn. ze zm. Ustawa z dnia 30 sierpnia 1991 roku o zakładach opieki zdrowotnej, Dz.U. 1991, nr 91 poz. 408. Ustawa z dnia 24 sierpnia 2007 roku o zmianie ustawy o zakładach opieki zdrowotnej oraz ustawy - Prawo o szkolnictwie wyższym, Dz.U. 2007, nr 176, poz. 1240.

Ustawa z dnia 5 grudnia 2008 roku o zapobieganiu oraz zwalczaniu zakażeń i chorób zakaźnych u ludzi, Dz.U. 2020, poz. 1845 tekst jedn. ze zm.

Ustawa z dnia 15 kwietnia 2011 roku o działalności leczniczej, Dz.U. 2021 poz. 711 tekst jedn. 


\section{Inne}

Projekt Kodeksu pracy z 2018 roku, https://www.gov.pl/web/rodzina/bip-teksty-projektu-kodeksu-pracy-i-projektu-kodeksu-zbiorowego-prawa-pracy-opracowane-przez-komisje-kodyfikacyjna-prawa-pracy (dostęp: 14 marca 2021).

Stanowisko Departamentu Prawnego Państwowej Inspekcji Pracy w sprawie charakteru prawnego dyżuru medycznego po 1 stycznia 2008 roku, https://www.pip.gov.pl/pl/porady-prawne/ czas-pracy/16083,stanowisko-departamentu-prawnego-w-sprawie-charakteru-prawnego-dyzuru-medycznego-po-1-stycznia-2008-r-.html (dostęp: 14 marca 2021).

Wniosek dotyczący dyrektywy Parlamentu Europejskiego i Rady zmieniającej dyrektywę 2003/88/ WE dotyczącą niektórych aspektów organizacji czasu pracy, COM/2004/0607 końcowy COD 2004/0209, https://eur-lex.europa.eu/legal-content/EN/TXT/?uri=COM\%3A2004\% 3A0607\%3AFIN (dostęp: 14 marca 2021). 